\title{
Roseovarius pacificus sp. nov., isolated from deep-sea sediment
}

\author{
Correspondence \\ Zongze Shao \\ shaozz@163.com
}

\author{
Baojiang Wang, Tianfeng Tan and Zongze Shao
}

Key Laboratory of Marine Biogenetic Resources, Third Institute of Oceanography, State Oceanic Administration, PR China

\begin{abstract}
An aerobic, Gram-negative, ovoid to rod-shaped bacterial isolate, strain $81-2^{\top}$, was isolated from deep-sea sediment of the Western Pacific Ocean. Strain $81-2^{\top}$ was motile, formed faint pink colonies, and was catalase-positive, weakly positive for oxidase and required $\mathrm{NaCl}$ for growth. It did not synthesize bacteriochlorophyll $a$ and its DNA G+C content was $62.3 \mathrm{~mol} \%$. The $16 \mathrm{~S}$ rRNA gene sequence of strain $81-2^{\top}$ indicated that it was a member of the Roseobacter clade of the class Alphaproteobacteria, with moderate bootstrap support for inclusion in the genus

Roseovarius. Its closest phylogenetic neighbour was the type strain of Roseovarius nubinhibens, which shared $95.8 \% 16 \mathrm{~S}$ rRNA gene sequence similarity; strain $81-2^{\top}$ was $<95.0 \%$ similar to strains of other related species and genera. Phenotypic, chemotaxonomic and phylogenetic data support assignment of this strain to the genus Roseovarius as a representative of a novel species. The name Roseovarius pacificus sp. nov. is proposed, with strain $81-2^{\top}$ (=MCCC $1 \mathrm{A00293^{ \top }}=$ CGMCC $1.7083^{\top}=$ LMG $24575^{\top}$ ) as the type strain.
\end{abstract}

The Roseobacter clade falls within the $\alpha-3$ subclass of the class Alphaproteobacteria, with members sharing $>89 \%$ 16S rRNA gene sequence similarity. The Roseobacter clade is one of the major bacterial groups found in the world's oceans and members are well represented in diverse marine habitats, from coastal to open oceans and from sea-ice to sea floor (Buchan et al., 2005).

The genus Roseovarius was created by Labrenz et al. (1999) and, at the time of writing, included four species isolated from various sources. Roseovarius crassostreae was obtained from cultured Crassostrea virginica (Boettcher et al., 1999, 2005), Roseovarius tolerans was obtained from Ekho Lake (Labrenz et al., 1999), Roseovarius nubinhibens was isolated from seawater of coastal Georgia (González et al., 2003) and Roseovarius mucosus was isolated from a culture of the alga Alexandrium ostenfeldii $\mathrm{KO} 287$ (Biebl et al., 2005). In this study, a novel strain, $81-2^{\mathrm{T}}$, was characterized morphologically, physiologically and biochemically, and results suggest that it should be classified as a representative of a novel species of the genus Roseovarius.

Strain $81-2^{\mathrm{T}}$ was isolated from a polycyclic aromatic hydrocarbon-degrading bacterial consortium that was enriched using pyrene as sole carbon source. A sediment sample was obtained from the Western Pacific Ocean

Abbreviation: Bchl a, bacteriochlorophyll a.

The GenBank/EMBL/DDBJ accession number for the 16S rRNA gene sequence of strain $81-2^{\top}$ is DQ120726.

A profile of the plasmid observed in strain $81-2^{\top}$ (Fig. S1) is available with the online version of this paper. $\left(16^{\circ} 59.9412^{\prime} \mathrm{N} 124^{\circ} 58.2958^{\prime} \mathrm{E}\right)$ using a multicorer sampler at a water depth of $2682 \mathrm{~m}$. The sample was enriched in a $250 \mathrm{ml}$ flask containing $\mathrm{MM}$ medium $\left[\left(\mathrm{l}^{-1}\right)\right.$ $3.5 \mathrm{~g} \mathrm{MgSO}_{4} .7 \mathrm{H}_{2} \mathrm{O}, 0.05 \mathrm{~g} \mathrm{CaCl}_{2}, 24 \mathrm{~g} \mathrm{NaCl}, 0.35 \mathrm{~g} \mathrm{KCl}$, $1.0 \mathrm{~g} \mathrm{NH}_{4} \mathrm{NO}_{3}, 1.0 \mathrm{~g} \mathrm{KH}_{2} \mathrm{PO}_{4}, 1.0 \mathrm{~g} \mathrm{~K}_{2} \mathrm{HPO}_{4}, 0.01 \mathrm{~g} \mathrm{FeCl}_{3}$, $1 \times 10^{-4} \mathrm{~g} \mathrm{ZnSO}_{4} .7 \mathrm{H}_{2} \mathrm{O}, 24 \mathrm{mg} \mathrm{SrCl}_{2} .6 \mathrm{H}_{2} \mathrm{O}, 0.08 \mathrm{~g} \mathrm{KBr}$ and $1.0 \mathrm{~g}$ pyrene, adjusted to $\mathrm{pH}$ 7.4]. After a series of transfers, a stable consortium was obtained and the culture was spread onto HLB agar plates and incubated at $28{ }^{\circ} \mathrm{C}$ for 4 days. HLB is modified Luria-Bertani medium (Sambrook et al., 1989) containing increased $\mathrm{NaCl}(24 \mathrm{~g}$ $\mathrm{NaCl} 1^{-1}$ ). Colonies with different appearances were selected for further analysis. A colony exhibiting a pink colour on HLB was purified by transferring it to new plates and designated strain $81-2^{\mathrm{T}}$. Pure cultures were preserved as a glycerol suspension $(20 \%, \mathrm{w} / \mathrm{v})$ at $-70{ }^{\circ} \mathrm{C}$.

Bacteriochlorophyll $a$ (Bchl $a$ ) detection was performed by spectrometric analysis of methanolic cell extracts. In the absence of light, $50 \mathrm{ml}$ liquid culture was centrifuged at $5000 \mathrm{~g}$ for $10 \mathrm{~min}$ and resuspended in an ice-cold acetone/ methanol solution $(7: 2, \mathrm{v} / \mathrm{v})$ at $-20{ }^{\circ} \mathrm{C}$ for $12 \mathrm{~h}$. Cell fragments were then removed by centrifugation. The characteristic absorption peaks were observed by spectrophotometric analysis at 200-900 $\mathrm{nm}$.

Extraction of genomic DNA was carried out by standard methods (Ausubel et al., 1995). The DNA G+C content was determined by HPLC after digestion of the DNA with nuclease P1 (Tamaoka \& Komagata, 1984; Mesbah \& Whitman, 1989). The 16S rRNA gene was amplified by PCR using primers 16SF (positions 8-27, Escherichia coli 
Table 1. Differential characteristics of Roseovarius pacificus $81-2^{\top}$ and type strains of related species

Strains: 1, Rva. pacificus sp. nov. 81-2 (this study); 2, Rva. tolerans EL-172 ${ }^{\mathrm{T}}$ (Labrenz et al., 1999; Biebl et al., 2005); 3, Rva. nubinhibens ISM ${ }^{\mathrm{T}}$ (González et al., 2003; Biebl et al., 2005); 4, Rva. crassostreae CV919-312 ${ }^{\mathrm{T}}$ (Boettcher et al., 2005); 5, Rva. mucosus DFL-24 $4^{\mathrm{T}}$ (Biebl et al., 2005); 6, Leisingera methylohalidivorans $\mathrm{MB}^{\mathrm{T}}$ (Schaefer et al., 2002; Martínez-Cánovas et al., 2004; Martens et al., 2006); 7, Phaeobacter gallaeciensis BS107 ${ }^{\mathrm{T}}$ (Ruiz-Ponte et al., 1998; Martens et al., 2006); 8, Marinovum algicola ATCC 51440 (Lafay et al., 1995; Labrenz et al., 1999; Martínez-Cánovas et al., 2004; Martens et al., 2006); 9, Silicibacter pomeroyi DSS-3 ${ }^{\mathrm{T}}$ (González et al., 2003); 10, Sagittula stellata E-37 ${ }^{\mathrm{T}}$ (González et al., 1997; Labrenz et al., 1999); 11, Antarctobacter heliothermus EL-219 (Labrenz et al., 1998, 1999); 12, Roseobacter denitrificans $\mathrm{DSM} 7001^{\mathrm{T}}$ (Shiba, 1991; Labrenz et al., 1999; Martens et al., 2006); 13, Sulfitobacter mediterraneus DSM 12244 ${ }^{\mathrm{T}}$ (Pukall et al., 1999; Martínez-Cánovas et al., 2004). +, Positive; -, negative; v, variable; w, weak; ND, not determined; TR, trace.

\begin{tabular}{|c|c|c|c|c|c|c|c|c|c|c|c|c|c|}
\hline Characteristic & 1 & 2 & 3 & 4 & 5 & 6 & 7 & 8 & 9 & 10 & 11 & 12 & 13 \\
\hline Cell shape & $\begin{array}{l}\text { Ovoid to } \\
\text { rods }\end{array}$ & Short rods & Short rods & $\begin{array}{l}\text { Ovoid to } \\
\text { rods }\end{array}$ & Short rods & $\begin{array}{l}\text { Rods/ ovoid } \\
\text { rods }\end{array}$ & $\begin{array}{c}\text { Ovoid } \\
\text { rods }\end{array}$ & Ovoid rods & Rods & Rod & Rod & Ovoid rods & Rods \\
\hline Source of isolation & $\begin{array}{c}\text { Western } \\
\text { Pacific } \\
\text { Ocean }\end{array}$ & Antarctic lake & $\begin{array}{l}\text { Seawater } \\
\text { (Caribbean } \\
\text { Sea) }\end{array}$ & $\begin{array}{l}\text { Animal } \\
\text { (Crassostrea } \\
\text { virginica) }\end{array}$ & $\begin{array}{c}\text { Marine } \\
\text { dinoflagel- } \\
\text { late }\end{array}$ & Seawater & Seawater & $\begin{array}{l}\text { Marine } \\
\text { dinoflagel- } \\
\text { late }\end{array}$ & Seawater & Seawater & Ekho Lake & Seaweed & Seawater \\
\hline Colony colour & Faintly pink & Red & $\begin{array}{l}\text { Cream } \\
\text { margin and } \\
\text { brown } \\
\text { centre }\end{array}$ & Pink-beige & $\begin{array}{l}\text { Whitish to } \\
\text { faintly pink }\end{array}$ & - & Brown & Beige-pink & Cream & Cream & $\begin{array}{r}\text { Brown- } \\
\text { yellow }\end{array}$ & Pink & Cream \\
\hline Motility & + & + (tumbling) & + & + & - & + & + & + & + & - & $\mathrm{V}$ & + & + \\
\hline Flagella & Subpolar & Not found & $\mathrm{ND}$ & $\begin{array}{l}\text { Subpolar to } \\
\text { lateral }\end{array}$ & Not found & Subpolar & Polar & Subpolar & Polar & + & Subpolar & Subpolar & Subpolar \\
\hline Oxidase & + & $\mathrm{w}$ & $\mathrm{v}$ & + & + & + & + & + & + & + & + & + & + \\
\hline Catalase & + & + & + & + & + & + & + & + & + & + & + & + & + \\
\hline Anaerobic growth & - & - & - & - & - & - & - & - & - & - & + & - & - \\
\hline Bchl $a$ & - & + & Not found & - & TR & - & - & - & - & - & - & + & - \\
\hline $\mathrm{Na}^{+}$requirement & + & + & + & + & + & + & ND & + & + & + & + & ND & + \\
\hline \multicolumn{14}{|l|}{$\begin{array}{l}\text { Growth in } \mathrm{NaCl} \\
(\%):\end{array}$} \\
\hline Range & $1-15$ & $1-15$ & $0.8-4.7$ & ND & $0.3-10$ & $1-6$ & $0.6-11.7$ & $0.5-12$ & ND & ND & $1-10$ & ND & $0.2-8.0$ \\
\hline Optimum & $2-12$ & $1-8$ & $1.1-2.3$ & $1-1.5$ & $1-7$ & 3 & 1.2 & $\mathrm{ND}$ & $0.6-2.3$ & $\mathrm{ND}$ & $2-6$ & ND & $1.5-2$ \\
\hline $\begin{array}{l}\text { Optimum growth } \\
\text { temperature }\left({ }^{\circ} \mathrm{C}\right)\end{array}$ & 25 & $8.5-33.5$ & 30 & 34 & 31 & 27 & $23-27$ & $25-30$ & 30 & 30 & $16-26$ & $20-30$ & $17-28$ \\
\hline \multicolumn{14}{|l|}{ Growth at: } \\
\hline $4{ }^{\circ} \mathrm{C}$ & $\mathrm{w}$ & + & - & - & - & + & - & - & - & - & $\mathrm{ND}$ & + & + \\
\hline $37^{\circ} \mathrm{C}$ & + & + & + & + & + & - & + & + & + & + & + & - & - \\
\hline pH optimum & $6.2-8.5$ & $6.2-9.0$ & ND & $6.5-8.0$ & $6.5-8.8$ & 7.7 & 7.0 & 7.5 & $\mathrm{ND}$ & 7.5 & $6.9-7.8$ & $7.0-8.0$ & $7.0-7.5$ \\
\hline Aesculinase & - & $\mathrm{ND}$ & ND & - & $\mathrm{ND}$ & $\mathrm{ND}$ & $\mathrm{ND}$ & + & ND & $\mathrm{ND}$ & $\mathrm{ND}$ & $\mathrm{ND}$ & $\mathrm{ND}$ \\
\hline$\beta$-Galactosidase & - & $\mathrm{ND}$ & ND & - & $\mathrm{ND}$ & $\mathrm{ND}$ & $\mathrm{ND}$ & + & $\mathrm{ND}$ & $\mathrm{ND}$ & $\mathrm{ND}$ & $\mathrm{ND}$ & $\mathrm{ND}$ \\
\hline Gelatinase & - & - & - & - & + & - & - & + & + & - & + & + & + \\
\hline Amylase & - & - & - & $\mathrm{ND}$ & - & - & - & + & - & - & $\mathrm{v}$ & - & $\mathrm{ND}$ \\
\hline Tween 80 & - & - & - & ND & - & - & - & - & - & - & - & + & $\mathrm{ND}$ \\
\hline \multicolumn{14}{|l|}{ Reduction of: } \\
\hline Nitrate to nitrite & - & - & - & + & $\mathrm{ND}$ & - & - & - & - & - & + & + & - \\
\hline
\end{tabular}




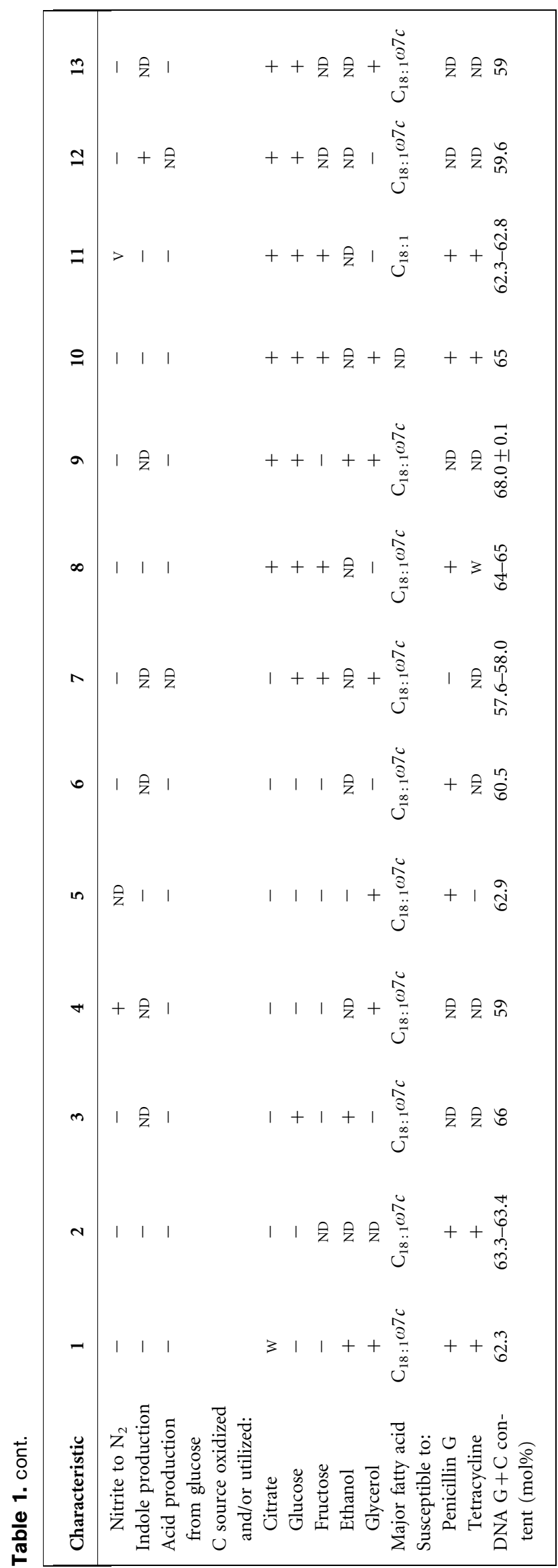

numbering; 5'-AGAGTTTGATCCTGGCTCAG-3') and 16SR (positions 1512-1493; 5'-ACGGCTACCTTGTTACGACT-3'). Thermal cycles were performed on a T3 thermal cycler (Biometra). Amplified DNA fragments were purified and recovered by using an EZNA Cycle-Pure kit (Omega Bio-Tek). Sequencing was carried out on a model 3730 automated DNA sequencer using a BigDye Terminator Cycle Sequencing kit (Applied Biosystems).

The sequences of strain $81-2^{\mathrm{T}}$ and reference bacterial species that were obtained from GenBank were aligned manually with DNAMAN software, version 6 (Lynnon Biosoft). Phylogenetic analysis of $16 \mathrm{~S}$ rRNA gene sequences was also performed with DNAMAN software.

The morphological, physiological and biochemical characteristics of strain $81-2^{\mathrm{T}}$ are given in the species description (see below) and Table 1. Properties that differentiate strain $81-2^{\mathrm{T}}$ from related members of the Roseobacter clade are shown in Table 1. Strain $81-2^{\mathrm{T}}$ grew well on HLB medium. Colonies were whitish to faintly pink, circular, moist-appearing, convex, and had entire margins and smooth surfaces. When grown in a medium containing $10 \mathrm{~g}$ peptone $\mathrm{l}^{-1}$ and $5 \mathrm{~g}$ yeast extract $\mathrm{l}^{-1}$, the strain grew readily in $2-12 \% \mathrm{NaCl}$, although growth was slower at 2 and $12 \% \mathrm{NaCl}$. No growth occurred in the absence of $\mathrm{NaCl}$. For carbon source utilization tests (described below), a salinity of $2.4 \% \mathrm{NaCl}$ was used. Within the temperature range tested $\left(4-45^{\circ} \mathrm{C}\right)$, growth was observed throughout, with maximum growth observed at $25{ }^{\circ} \mathrm{C}$. Growth was equally good at an initial $\mathrm{pH}$ between 6.2 and 8.5 , but not at pH 5.2 or 9.1. Strain $81-2^{\mathrm{T}}$ did not produce Bchl $a$ in the dark as the characteristic absorption peak between 400 and $900 \mathrm{~nm}$ was not detected. Agarose gel electrophoresis of chromosomal DNA showed that strain $81-2^{\mathrm{T}}$ contained a small plasmid that has not been reported in other species of the genus (see Supplementary Fig. S1 in IJSEM Online). The plasmid could be digested by HindIII (Takara), giving a linear product of $\sim 5.0 \mathrm{~kb}$.

A comparison of $16 \mathrm{~S}$ rRNA gene sequences revealed highest similarities between strain $81-2^{\mathrm{T}}$ and type strains of the following species: Rva. nubinhibens (95.8\%); Rva. crassostreae (94.4\%); Rva. tolerans (94.9\%); Rva. mucosus (94.3\%); Phaeobacter gallaeciensis (94.3\%); Roseobacter litoralis (92.7\%); and Marinovum algicola (94.4\%). The strain joined the clade comprising species of the genus Roseovarius. Following these discoveries, detailed phylogenetic analysis of strain $81-2^{\mathrm{T}}$ and strains of species of the Roseobacter clade with validly published names was performed; the phylogenetic tree based on analysis of the $16 \mathrm{~S}$ rRNA gene (1428 bp) indicates that strain $81-2^{\mathrm{T}}$, together with other Roseovarius species, formed a clearly separate group within the Roseobacter clade (Fig. 1). The same topology was also found in trees based on maximumlikelihood and maximum-parsimony algorithms.

The oxidation of various substrates was determined by using the Biolog system as described previously (Ivanova et al., 1998). GN2 Microplates were selected and, after 


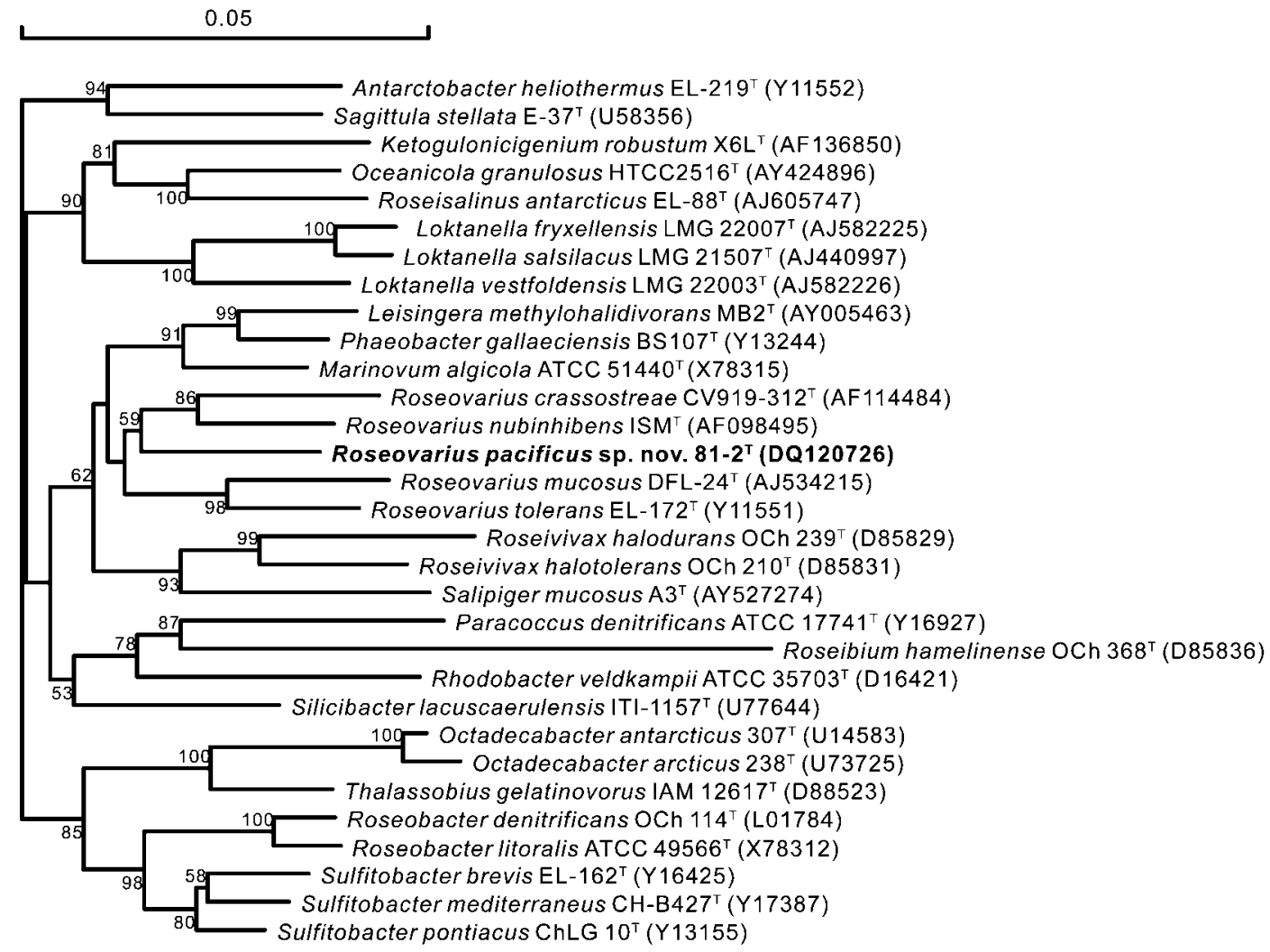

Fig. 1. A complete neighbour-joining tree showing the phylogenetic position of strain $81-2^{\top}$ and representatives of some other related taxa, based on 16S rRNA gene sequences. Bootstrap values (expressed as percentages of 1000 replications) are shown at branch points. Bar, 0.05 substitutions per nucleotide position.

adding $150 \mu \mathrm{l}$ liquid culture with an $\mathrm{NaCl}$ concentration of $2.4 \%$, plates were incubated at $25{ }^{\circ} \mathrm{C}$. Tests for utilization of various other organic substrates as sole carbon sources at a concentration of $0.1 \%(\mathrm{w} / \mathrm{v})$ were performed in $5 \mathrm{ml}$ MM medium. Catalase and oxidase activities and the hydrolysis of starch were determined as described by Cowan \& Steel (1965). Aesculin hydrolysis and nitrate reduction were investigated as described by Lányí (1987). Other physiological and biochemical tests were performed with the API 20E system (bioMérieux) using API medium with an $\mathrm{NaCl}$ concentration of $24 \mathrm{~g} \mathrm{l}^{-1}$.

Susceptibility to different antibiotics was tested on HLB plates by using discs containing the following antibiotics $(\mu \mathrm{g})$ : fortum, 30; cefuroxime, 30; cephradin, 100; cefazolin, 30; cefalexin, 30; piperacillin, 100; carbenicillin, 100; ampicillin, 10; oxacillin, 1; penicillin, 10; erythromycin, 15; minomycin, 30; vibramycin, 30; tetracycline, 30; neomycin, 30; kanamycin, 30; gentamicin, 10; amikacin, 30; cefobid, 75; rocephin, 30; vancomycin, 30; polymyxin B, 300; ofloxacin, 5; midecamycin, 30; ciprofloxacin, 5; norfloxacin, 10; furazolidone, 300; co-trimoxazole, 75; chloromycetin, 30; and clindamycin, 2.

Cell shape and motility were observed by light microscopy (Olympus). Cell size and more detailed morphology were determined by transmission electron microscopy, for which cells were suspended and absorbed on a Formvar, carbon-coated grid, then stained with phosphotungstic acid; after air-drying, the grid was examined by using an $\mathrm{H}$ 600 transmission electron microscope (Hitachi). Cells were motile and ovoid to rod-shaped, $0.48-0.58 \times 0.94-1.74 \mu \mathrm{m}$ in size. In addition, cells possessed at least one subpolar flagellum (Fig. 2).

Cellular fatty acid analysis was carried out as described by Mrozik et al. (2004). Analysis of fatty acid methyl esters

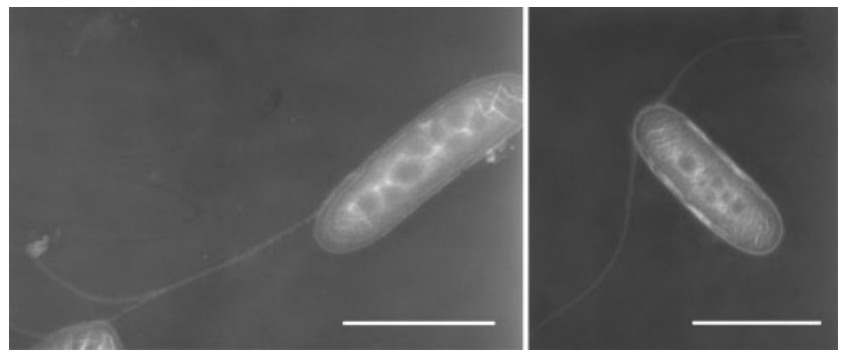

Fig. 2. Transmission electron micrographs of negatively stained cells grown on HLB agar for $72 \mathrm{~h}$. Bars, $1 \mu \mathrm{m}$. 
was performed on a GC-MS (QP2010; Shimadzu) equipped with an RTX-5MS column. Peaks were identified with pre-installed software, GC-MS Postrun analysis software (version 2.10; Shimadzu). The fatty acid profile of strain $81-2^{\mathrm{T}}$ comprised unsaturated, straight-chain and hydroxy fatty acids. This fatty acid profile was similar to those of other Roseovarius species, although there were differences in the proportions of some fatty acids, perhaps because of differences in cultivation conditions (González et al., 2003; Table 2). As in most members of the class Alphaproteobacteria, $\mathrm{C}_{18: 1} \omega 7 c$ was the predominant component, amounting to more than $70 \%$ total fatty acid content. $\mathrm{C}_{12: 0} 3-\mathrm{OH}$ was present in both strain $81-2^{\mathrm{T}}$ and Rva. nubinhibens, whereas Rva. mucosus and Rva. tolerans contained $\mathrm{C}_{12: 1} 3-\mathrm{OH}$.

Distance analyses consistently placed strain $81-2^{\mathrm{T}}$ in the genus Roseovarius as shown in Fig. 1. However, a reliability value of $59 \%$ indicated that the branching pattern was not very stable and did not provide strong support for inclusion of this organism in the genus Roseovarius. A comparison of phenotypic characteristics showed that properties of strain $81-2^{\mathrm{T}}$ were consistent with those of members of the genus Roseovarius (Table 1) and its DNA $\mathrm{G}+\mathrm{C}$ content was in the range $62-64 \mathrm{~mol} \%$ (Labrenz et al., 1999). Thus, despite the low bootstrap value to the Roseovarius group, the above analyses support the proposal that strain $81-2^{\mathrm{T}}$ represents a novel species of the genus Roseovarius.

In conclusion, phenotypic and phylogenetic analyses support placement of this strain as a novel species in the

Table 2. Fatty acid composition (\%) of some species of the genus Roseovarius

Strains: 1 , Rva. pacificus sp. nov. $81-2^{\mathrm{T}}$ (data from this study); 2, Rva. tolerans EL-172 ${ }^{\mathrm{T}}$ (Labrenz et al., 1999); 3, Rva. nubinhibens $\mathrm{ISM}^{\mathrm{T}}$ (González et al., 2003); 4, Rva. crassostreae (12 strains; Boettcher et al., 2005); 5, Rva. mucosus DFL-24 (Biebl et al., 2005). -, Not detected.

\begin{tabular}{|lccccc|}
\hline Fatty acid & $\mathbf{1}$ & $\mathbf{2}$ & $\mathbf{3}$ & $\mathbf{4}$ & $\mathbf{5}$ \\
\hline $\mathrm{C}_{10: 0} 3-\mathrm{OH}$ & - & - & - & $2.1 \pm 0.3$ & 0.7 \\
$\mathrm{C}_{12: 0}$ & 4.24 & - & 3.3 & - & 3.1 \\
$\mathrm{C}_{12: 0} 2-\mathrm{OH}$ & - & 2.4 & - & - & 2.5 \\
$\mathrm{C}_{12: 0} 3-\mathrm{OH}$ & 4.56 & - & 1.5 & - & - \\
$\mathrm{C}_{12: 1} 3-\mathrm{OH}$ & - & 3.6 & - & - & 1.7 \\
$\mathrm{C}_{16: 1} \omega 7 c$ & - & - & 1.0 & - & - \\
$\mathrm{C}_{16: 1} \omega 9 c$ & 1.35 & 0.8 & - & - & 0.8 \\
$\mathrm{C}_{16: 0}$ & 6.21 & 6.2 & 9.8 & $3.6 \pm 0.9$ & 13.1 \\
$\mathrm{C}_{17: 0}$ & - & - & - & - & - \\
$\mathrm{C}_{18: 0}$ & 3.8 & 0.8 & 0.6 & $0.7 \pm 0.3$ & 1.8 \\
$\mathrm{Methyl}_{18: 0} 0$ & - & - & - & - & 2.1 \\
$\mathrm{C}_{18: 1} \omega 7 c$ & 73.95 & 70.2 & 76.4 & $85.2 \pm 1.7$ & 69.4 \\
Methyl & - & - & - & $0.8 \pm 0.2$ & 2.1 \\
$\mathrm{C}_{18: 1} \omega 7$ & & & & & \\
$\mathrm{Cyclo}_{19: 1}$ & - & - & 5.3 & - & 3.7 \\
$\mathrm{C}_{18: 2}$ & - & 10.6 & - & - & - \\
\hline
\end{tabular}

genus Roseovarius. The proposed name is Roseovarius pacificus sp. nov.

\section{Description of Roseovarius pacificus sp. nov.}

Roseovarius pacificus (pa.ci'fi.cus. M.L. adj. pacificus pertaining to the Pacific Ocean from which the type strain was isolated).

Cells are aerobic, non-spore-forming, Gram-negative and ovoid to rod-shaped, $0.48-0.58 \times 0.94-1.74 \mu \mathrm{m}$. Actively motile; at least one subpolar flagellum may be present. On HLB agar plates, small, wettish, smooth, faint pink colonies develop in 3-5 days. Optimal growth is observed at $25^{\circ} \mathrm{C}$, salinities of $2-12 \%$ and $\mathrm{pH}$ between 6.2 and 8.5. There is an absolute requirement for sodium ions. Does not contain Bchl $a$. Cells are positive for oxidase and catalase, and negative for nitrate reduction, hydrolysis of starch and gelatin liquefaction. $\mathrm{H}_{2} \mathrm{~S}$ and indole are not produced. In assays with the API 20E system, lysine decarboxylase is present, but $\beta$-galactosidase, arginine dihydrolase, ornithine decarboxylase, urease and tryptophan deaminase are absent. Voges-Proskauer test is positive. Oxidizes the following substrates: methyl pyruvate, monomethyl succinate, acetic acid, formic acid, $\alpha$-hydroxybutyric acid, $\beta$ hydroxybutyric acid, $\gamma$-hydroxybutyric acid, itaconic acid, $\alpha$-ketobutyric acid, $\alpha$-ketoglutaric acid, $\alpha$-ketovaleric acid, DL-lactic acid, propionic acid, succinic acid, succinamic acid, L-alanine, L-alanyl-glycine, L-asparagine, L-aspartic acid, L-glutamic acid, glycyl-L-glutamic acid, L-histidine, Lornithine, L-proline, L-pyroglutamic acid, L-serine, $\gamma$ aminobutyric acid, 2-aminoethanol, ethanol and glycerol. The following carbon sources are oxidized weakly: Tween 40, cis-aconitic acid, citric acid, p-hydroxyphenylacetic acid, D-saccharic acid, bromosuccinic acid, D-alanine, DLcarnitine and urocanic acid. Susceptible to fortum, cefuroxime, cephradin, cefazolin, cefalexin, piperacillin, carbenicillin, ampicillin, penicillin G, minomycin, vibramycin, tetracycline, neomycin, kanamycin, gentamicin, amikacin, cefobid, rocephin, polymyxin B, ofloxacin, midecamycin, ciprofloxacin, norfloxacin and chloromycetin, but not to oxacillin, erythromycin, vancomycin, furazolidone, co-trimoxazole or clindamycin. The major fatty acid ( $>70 \%$ total fatty acids) is $\mathrm{C}_{18: 1} \omega 7 c$. Other phenotypic characteristics are given in Table 1.

The type strain is $81-2^{\mathrm{T}}\left(=\mathrm{MCCC} 1 \mathrm{~A} 00293^{\mathrm{T}}=\mathrm{CGMCC}\right.$ $1.7083^{\mathrm{T}}=\mathrm{LMG} 24575^{\mathrm{T}}$ ), isolated from deep-sea sediment of the Western Pacific Ocean. The DNA G $+\mathrm{C}$ content of the type strain is $62.3 \mathrm{~mol} \%$ (determined by HPLC).

\section{Acknowledgements}

This work was supported by the National Basic Research Program of China (no. 2004CB719601) and the National Infrastructure of Natural Resources for Science and Technology Program of China (No. 2005DKA21209) COMRA program (no. DYXM115-022-05). 


\section{References}

Ausubel, F. M., Brent, R., Kingston, R. E., Moore, D. D., Seidman, J. G., Smith, J. A. \& Struhl, K. (editors) (1995). Short Protocols in Molecular Biology: a Compendium of Methods from Current Protocols in Molecular Biology, 3rd edn. New York: Wiley.

Biebl, H., Allgaier, M., Lünsdorf, H., Pukall, R., Tindall, B. J. \& Wagner-Döbler, I. (2005). Roseovarius mucosus sp. nov., a member of the Roseobacter clade with trace amounts of bacteriochlorophyll $a$. Int J Syst Evol Microbiol 55, 2377-2383.

Boettcher, K. J., Barber, B. J. \& Singer, J. T. (1999). Use of antibacterial agents to elucidate the etiology of juvenile oyster disease (JOD) in Crassostrea virginica and numerical dominance of an $\alpha$ proteobacterium in JOD-affected animals. Appl Environ Microbiol 65, 2534-2539.

Boettcher, K. J., Geaghan, K. K., Maloy, A. P. \& Barber, B. J. (2005). Roseovarius crassostreae sp. nov., a member of the Roseobacter clade and the apparent cause of juvenile oyster disease (JOD) in cultured Eastern oysters. Int J Syst Evol Microbiol 55, 1531-1537.

Buchan, A., González, J. M. \& Moran, M. A. (2005). Overview of the marine Roseobacter lineage. Appl Environ Microbiol 71, 5665-5677.

Cowan, S. T. \& Steel, K. J. (1965). Manual for the Identification of Medical Bacteria. London: Cambridge University Press.

González, J. M., Mayer, F., Moran, M. A., Hodson, R. E. \& Whitman, W. B. (1997). Sagittula stellata gen. nov., sp. nov., a lignin-transforming bacterium from a coastal environment. Int J Syst Bacteriol 47, 773-780.

González, J. M., Covert, J. S., Whitman, W. B., Henriksen, J. R., Mayer, F., Scharf, B., Schmitt, R., Buchan, A., Fuhrman, J. A. \& other authors (2003). Silicibacter pomeroyi sp. nov. and Roseovarius nubinhibens sp. nov., dimethylsulfoniopropionate-demethylating bacteria from marine environments. Int J Syst Evol Microbiol 53, 1261-1269.

Ivanova, E. P., Kiprianova, E. A., Mikhailov, V. V., Levanova, G. F., Garagulya, A. D., Gorshkova, N. M., Vysotskii, M. V., Nicolau, D. V., Yumoto, N. \& other authors (1998). Phenotypic diversity of Pseudoalteromonas citrea from different marine habitats and emendation of the description. Int J Syst Bacteriol 48, 247-256.

Labrenz, M., Collins, M. D., Lawson, P. A., Tindall, B. J., Braker, G. \& Hirsch, P. (1998). Antarctobacter heliothermus gen. nov., sp. nov., a budding bacterium from hypersaline and heliothermal Ekho Lake. Int J Syst Bacteriol 48, 1363-1372.

Labrenz, M., Collins, M. D., Lawson, P. A., Tindall, B. J., Schumann, P. \& Hirsch, P. (1999). Roseovarius tolerans gen. nov., sp. nov., a budding bacterium with variable bacteriochlorophyll a production from hypersaline Ekho Lake. Int J Syst Bacteriol 49, 137-147.

Lafay, B., Ruimy, R., Rausch de Traubenberg, C., Breittmayer, V., Gauthier, M. J. \& Christen, R. (1995). Roseobacter algicola sp. nov., a new marine bacterium isolated from the phycosphere of the toxinproducing dinoflagellate Prorocentrum lima. Int J Syst Bacteriol 45, 290-296.

Lányí, B. (1987). Classical and rapid identification methods for medically important bacteria. Methods Microbiol 19, 1-67.

Martens, T., Heidorn, T., Pukall, R., Simon, M., Tindall, B. J. \& Brinkhoff, T. (2006). Reclassification of Roseobacter gallaeciensis RuizPonte et al. 1998 as Phaeobacter gallaeciensis gen. nov., comb. nov., description of Phaeobacter inhibens sp. nov., reclassification of Ruegeria algicola (Lafay et al. 1995) Uchino et al. 1999 as Marinovum algicola gen. nov., comb. nov., and emended descriptions of the genera Roseobacter, Ruegeria and Leisingera. Int J Syst Evol Microbiol 56, 1293-1304.

Martínez-Cánovas, M. J., Quesada, E., Martínez-Checa, F., del Moral, A. \& Béjar, V. (2004). Salipiger mucescens gen. nov., sp. nov., a moderately halophilic, exopolysaccharide-producing bacterium isolated from hypersaline soil, belonging to the $\alpha$-Proteobacteria. Int J Syst Evol Microbiol 54, 1735-1740.

Mesbah, M. \& Whitman, W. B. (1989). Measurement of deoxyguanosine/thymidine ratios in complex mixtures by high-performance liquid chromatography for determination of the mole percentage guanine + cytosine of DNA. J Chromatogr 479, 297-306.

Mrozik, A., Piotrowska-Seget, Z. \& Labuzek, S. (2004). Changes in whole cell-derived fatty acids induced by naphthalene in bacteria from genus Pseudomonas. Microbiol Res 159, 87-95.

Pukall, R., Buntefuss, D., Frühling, A., Rohde, M., Kroppenstedt, R. M., Burghardt, J., Lebaron, P., Bernard, L. \& Stackebrandt, E. (1999). Sulfitobacter mediterraneus sp. nov., a new sulfite-oxidizing member of the $\alpha$-Proteobacteria. Int J Syst Bacteriol 49, 513-519.

Ruiz-Ponte, C., Cilia, V., Lambert, C. \& Nicolas, J. L. (1998). Roseobacter gallaeciensis sp. nov., a new marine bacterium isolated from rearings and collectors of the scallop Pecten maximus. Int J Syst Bacteriol 48, 537-542.

Sambrook, J., Fritsch, E. F. \& Maniatis, T. (1989). Molecular Cloning: a Laboratory Manual, 2nd edn. Cold Spring Harbor, NY: Cold Spring Harbor Laboratory.

Schaefer, J. K., Goodwin, K. D., McDonald, I. R., Murrell, J. C. \& Oremland, R. S. (2002). Leisingera methylohalidivorans gen. nov., sp. nov., a marine methylotroph that grows on methyl bromide. Int J Syst Evol Microbiol 52, 851-859.

Shiba, T. (1991). Roseobacter litoralis gen. nov., sp. nov., and Roseobacter denitrificans sp. nov., aerobic pink-pigmented bacteria which contain bacteriochlorophyll a. Syst Appl Microbiol 14, 140-145.

Tamaoka, J. \& Komagata, K. (1984). Determination of DNA base composition by reversed-phase high-performance liquid chromatography. FEMS Microbiol Lett 25, 125-128. 